\title{
Putting your heart on the line: an unusual case of a renal replacement complication
}

\author{
Christopher Myles Rowe, ${ }_{1}^{1}$ Sunit Davda, ${ }^{2}$ Bassam Fallouh, ${ }^{3}$ Mareen Joy ${ }^{4}$
}

${ }^{1}$ Intensive Care Unit, The Whittington Hospital, London, UK

${ }^{2}$ Department of Radiology, The Royal London Hospital, London, UK

${ }^{3}$ Department of Renal, Basildon Hospital, Basildon, UK

${ }^{4}$ Department of Rheumatology, Watford General Hospital, Watford, UK

\section{Correspondence to} Dr Christopher Myles Rowe, christopher.m.rowe@doctors. net.uk

Accepted 31 March 2015

\footnotetext{
To cite: Rowe $C M$, Davda S, Fallouh B, et al. BMJ Case Rep Published online: [please include Day Month Year] doi:10.1136/ bcr-2014-208970
}

\section{DESCRIPTION}

A patient with a background of end-stage renal failure secondary to reflux nephropathy, presented for elective replacement of her Tesio line (a type of tunnelled haemodialysis catheter consisting of two separate 10 French Bio-Flex polyurethane lines (a venous and an arterial line), each with a single cuff and side holes), which had been placed 5 years previously for dialysis.

Medical history included a failed cadaveric kidney transplant, failed arteriovenous fistulas and failed peritoneal dialysis. The patient had been having frequent repairs for cracks on the arterial line and was admitted to replace the Tesio line by an over-the-wire technique under ultrasound and fluoroscopy guidance. Initially, there was difficulty in passing the guide wire through the arterial and venous line lumens. Removal of the Tesio line proved impossible; fluid could not be drawn from the arterial line although there appeared to be good flow from the venous line. The patient was booked for surgical extraction: vascular surgeons dissected down to the internal jugular and removed the venous line easily; however, the arterial line was unyielding and appeared adherent intracardially. Review by cardiothoracic surgeons suspected the arterial line was impacted in the subclavian vein, innominate vein or superior vena cava, with removal requiring a sternotomy. The patient opted to bury the arterial Tesio line rather than undergo more extensive surgery.

Five days after manipulating the Tesio line, the patient complained of chest pain and had an elevated jugular venous pressure. Echocardiogram revealed a pericardial effusion, measuring $1.4 \mathrm{~cm}$ anteriorly, without evidence of tamponade. A few days later, the patient developed increasing dyspnoea and engorged neck veins, but had audible heart sounds on auscultation. Concomitantly, there was a haemoglobin drop from $90 \mathrm{~g} / \mathrm{L}$ to $75 \mathrm{~g} / \mathrm{L}$. A CT scan revealed a $9 \times 5 \mathrm{~cm}$ thrombus/haematoma compressing the right atrium (figure 1) and an urgent echocardiogram confirmed haemodynamic compromise from a pericardial haematoma severely compressing the right atrium as well as the right ventricle (figure 2).

The patient underwent an emergency sternotomy for control of tamponade. No definite point of bleeding was found in the right atrium, however, tissue glue was placed over a suspected source. The cardiac

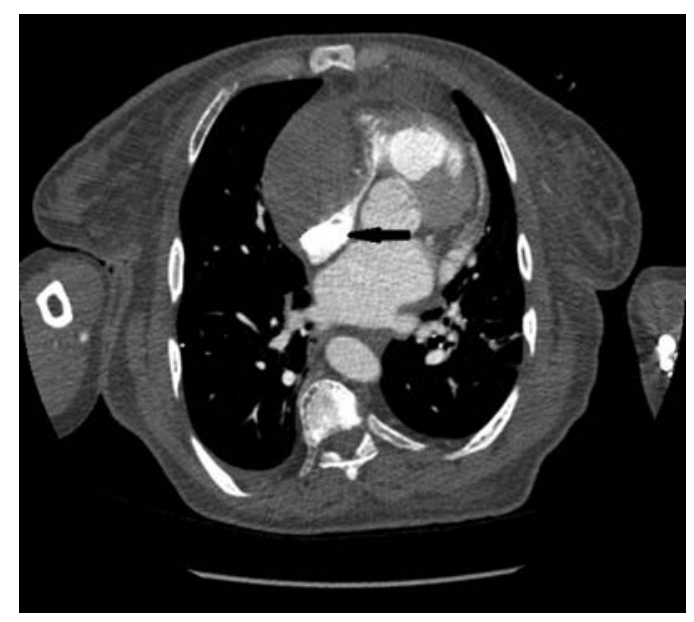

Figure 1 Axial view of the right atrium being compressed by the thrombus (indicated by the arrow).

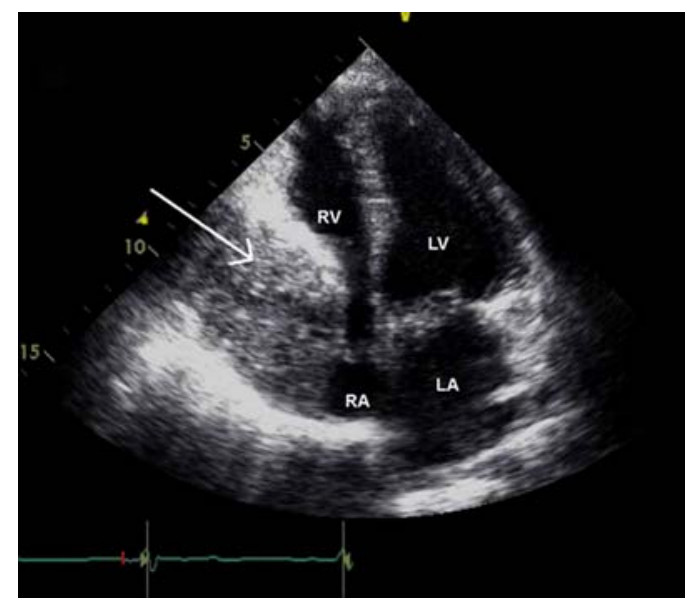

Figure 2 Echocardiogram (apical view) showing mass (white arrow) compressing the right atrium (RA) and right ventricle (RV) in late diastole. $L A$, left atrium, $L V$, left ventricle.

thrombus was evacuated and the Tesio line buried, as it was deemed too high risk to remove.

Postoperatively, the patient recovered well, although she developed Dressler's syndrome. Followup echocardiogram revealed an insignificant pericardial effusion and normal systolic function. The patient initially had a femoral Tesio line placed for haemodialysis, and has since had a successful kidney transplant. 


\section{Learning points}

- Tesio lines should ideally be placed under ultrasound and fluoroscopy guidance. Ultrasound enables identification of the target vein for initial access, and reduces complications including arterial puncture; fluoroscopy facilitates optimal line positioning and acquiring the high flow rates required for dialysis. ${ }^{1}$

- Adherent lines can be buried by ligating, dividing and removing the proximal section, burying the remnant under fascial pockets. ${ }^{2}$

- Adherent catheters or remnants of lines can be removed by a thoracotomy, with open dissection and evacuation of the line and any organised thrombus. ${ }^{2}$
Competing interests None.

Patient consent Not obtained.

Provenance and peer review Not commissioned; externally peer reviewed.

\section{REFERENCES}

1 Caridi JG, Grundy LS, Ross EA, et al. Interventional radiology placement of twin Tesio catheters for dialysis access: review of 75 patients. J Vasc Interv Radiol 1999; 10:78-83.

2 Hassan A, Khalifa M, Al-Akraa $M$, et al. Six cases of retained central venous haemodialysis access catheters. Nephrol Dial Transplant 2006;21:2005-8.

Copyright 2015 BMJ Publishing Group. All rights reserved. For permission to reuse any of this content visit http://group.bmj.com/group/rights-licensing/permissions.

BMJ Case Report Fellows may re-use this article for personal use and teaching without any further permission.

Become a Fellow of BMJ Case Reports today and you can:

- Submit as many cases as you like

- Enjoy fast sympathetic peer review and rapid publication of accepted articles

- Access all the published articles

- Re-use any of the published material for personal use and teaching without further permission

For information on Institutional Fellowships contact consortiasales@bmjgroup.com

Visit casereports.bmj.com for more articles like this and to become a Fellow 